\title{
Grameen Model and its ethical inclinations to Islamic Microfinance System: A Narrative-Textual Case Study
}

\author{
http://doi.org/10.21272/fmir.4(4).75-82.2020
}

\section{Hashim Sabo Bello}

Department of Business Administration and Management, School of Management Sciences, Abubakar Tatari Ali Polytechnic Bauchi, Bauchi State, Nigeria

\section{Mustapha Isah}

Department of Business Administration and Management, School of Management Studies, Abubakar Tatari Ali Polytechnic, Bauchi, Bauchi State, Nigeria

\section{Danlami Mohammed Lame}

Department of Banking and Finance, School of Management Studies, Abubakar Tatari Ali Polytechnic, Bauchi, Bauchi State, Nigeria

\begin{abstract}
This study focuses on an in-depth literature review to understand the Islamic microfinance as a system and grameen model as a concept all embedded in ethical concern for shared values. The concept of Grameen model and its ethical behavior have come to the fore in recent years in both developed and developing countries as a result of growing sense of corporate wrongdoing. The paper addresses the Grameen model and its ethical relevance to the benefits and success of Islamic microfinance in modern economy. the Grameen model has always offered the concept of social microfinance and such a model results in a more fulfilling work life and career. It is a radically different approach to doing business that emphasizes making money as its main goal, but not for the sake of wealth alone. In the same sense, Islamic microfinance aimed to focus on profit/loss sharing by using the funds on economic generating, investing and trading activities to make a profit and share that profit with all the depositors and shareholders, whilst protecting the fabric of our society without engaging in activities prohibited and harmful to the society. With this in mind, the entire money-making process can be sanctified so that it becomes a holy and noble pursuits. To achieve the above, this research paper draw lessons from the activities of an impeccable vision and salvaging activities of illustrious personage and veteran of many years standing from Bangladesh in his quest for promoting economic development and eradication of poverty among rural dwellers. This paper considered Islamic microfinance as a tool that could be used to achieve the necessary economic and social security that a country would need today leading to the overall development of humanity. As the western culture offers classic microfinance as the way to do business and in recent years, postmodernism has nominated a new model-microcredit to supersede the statuesque. This study, in general, recommended for the revitalization of Islamic civilization that would geared towards a paradigm shift to now novel concept of spiritual microfinance as a way to stimulate business and get closer to God simultaneously and as well stimulates social entrepreneurs who must focus on the goal of having a healthy income statement and simultaneously championing some sort of social healing enterprise.
\end{abstract}

Keywords: Ethical finance, Investment, Islamic microfinance, microcredit, Shari’ah.

JEL Classification: G00, G1, G21.

This work is licensed under a Creative Commons Attribution 4.0 International License

Cite as: Bello, H.S., Isah, M., Lame, D.M. (2020). Grameen Model and its ethical inclinations to Islamic Microfinance System: A Narrative-Textual Case Study. Financial Markets, Institutions and Risks, 4(4), 7582. http://doi.org/10.21272/fmir.4(4).75-82.2020.

C) The Authors, 2020. This article is published with open access at Sumy State University.

\section{Introduction}

The contemporary movement of Islamic finance is based on the belief that "all forms of interest are riba and hence prohibited" (Khan, 2013). In addition, Islamic law prohibits investing in businesses that are considered unlawful, or haraam (such as businesses that sell alcohol or pork, or businesses that produce media such as gossip columns or pornography, which are contrary to Islamic values). Furthermore, the Shari'ah prohibits 
what is called "Maysir" and "Gharar". Maysir is involved in contracts where the ownership of a good depends on the occurrence of a predetermined, uncertain event in the future whereas Gharar describes speculative transactions. Both concepts involve excessive risk and are supposed to foster uncertainty and fraudulent behaviour. Therefore, the use of all conventional derivative instruments is impossible in Islamic banking (Mervyn and Latifa, 2001). According to Zubair (2014) Islamic Microfinance means micro financing through interest free modes to the financially deprived and poor people to generate economic activities and making them self-employed for the ultimate economic prosperity. As per the latest research of the Centre of Excellence in Islamic Microfinance of AlHuda CIBE, the global Islamic Microfinance volume has reached at US \$1 billion with persistent growth and serving about 1.3 million beneficiaries but the share of Islamic Microfinance by less than 1\% of overall volume of Islamic Finance (US \$1.3 trillion), unveils its misfortune.

The concept of Islamic microfinance is recently developed dimension for micro financing to operate on Islamic modes and started in early 1960 from Latin America and South East Asia but Bangladesh has significant contribution to originate and approach the Paradigm concept of Islamic Micro financing. The Islamic micro financing is being done through different models such as: Grameen Model, Credit Union and Self Help Group in particulars but the microfinance sector is looking forward a compatible brain well trained and equipped to practice Islamic Microfinance using these models prudently. It is observed there are no specialized institutions for the education of Islamic Microfinance in particular. Absence of specialized education in Islamic Microfinance, particularly, is the crucial fact in Islamic Microfinance Industry, which is one of the hurdles for the promotion of the industry as well. There is an immediate need to initiate comprehensive degree programs on Islamic Microfinance globally (Zubair, 2014).

Microfinance is often defined as financial services for poor and low-income clients offered by different types of service providers. The term is often used more narrowly to refer to loans and other services from providers that identify themselves as "microfinance institutions" (MFIs). These institutions commonly tend to use new methods developed over the last 30 years to deliver very small loans to unsalaried borrowers, taking little or no collateral. These methods include group lending and liability, pre-loan savings requirements, gradually increasing loan sizes, and an implicit guarantee of ready access to future loans if present loans are repaid fully and promptly (Project Concern International, 2016). Microfinance programs have become a key component of the strategies of the struggle against poverty. The used financial innovations, whether the group loans, the use of non-financial services or dynamic incentive mechanisms as means to combat poverty, have increased the interest of governments and researchers. Microfinance includes a wide range of financial services such as the micro-credits, the small savings, the micro-insurance and the money transfers, which are aimed at the impoverished populations. This sector is experiencing an extremely rapid growth throughout the world (Zekri, 2013).

\section{Methodology}

Islamic finance is widely believed to be a subset of the socially responsible investment which in reality represent a good example of alternative ethical finance and investment in today's world. This study used both descriptive and explanatory, the methodology is Narrative-Textual Case Study (NTCS) method, which is preferred because of the absence of sequential data related to Islamic finance as indelible beneficial social goal. NTCS is a social science research method that employs intensively, the information, data and academic materials made available and easily accessible by information and communication technology facilities such as intranet, internet, World Wide Web, online databases, e-libraries, etcetera. The choice of this method is informed by the fact that NTCS combines the use of quantitative and qualitative observation, text content analysis and available official statistics in different proportions for problem-solving or problem-identification depending on the objectives of the research. This research study is basically non-empirical, but rather descriptive, since information is collected from the secondary source only. We used such appropriate technique in order to climb some salient points that will help in reaching an intensive analysis and conclusion which can pave leeway to resourceful and acceptable recommendations.

\section{The Readiness of Islamic Microfinance to go with Grameen Model}

Islamic banking has the same purpose as conventional banking: to make money for the banking institute by lending out capital while adhering to Islamic law. Because Islam forbids simply lending out money at interest, Islamic rules on transactions (known as Fiqh al-Muamalat) have been created to prevent it. The basic principle of Islamic banking is based on risk-sharing which is a component of trade rather than risk-transfer which is 
seen in conventional banking. Islamic banking introduces concepts such as profit sharing (Mudharabah), safekeeping (Wadiah), joint venture (Musharakah), cost plus (Murabahah), and leasing (Ijar). Interpretations of Shari'ah may vary slightly by country. According to Humayon Dar the Islamic Republic of Iran follows a more liberal interpretation of the Shariah than Malaysia and Pakistan, whose interpretation is more liberal than Turkey or Arab countries (Dar, 2010). Mohammed Ariff also found less exacting interpretation of Shari'ah compliance in Iran where the government had decreed "that government borrowing on the basis of a fixed rate of return from the nationalized banking system would not amount to interest and would hence be permissible" (Ariff, 1988).

In the middle of the 20th century some organizational entities were found to offer financial services complying with Islamic laws. The first, experimental, local Islamic bank was established in the late 1950s in a rural area of Pakistan which charged no interest on its lending (Wilson, 1983; Cengiz and Radi, 1989). A remarkable effort in Sharia compliant savings banking was undertaken in 1963 in rural Egypt by economist Ahmad Elnaggar to appeal to people who lacked confidence in state-run banks. The profit-sharing experiment, in the Nile Delta town of Mit Ghamr, did not specifically advertise its Islamic nature for fear of being seen as a manifestation of Islamic fundamentalism that was anathema to the Gamal Nasser regime. The experiment was shut down by the government in 1968 but was considered by many a success Kepel (2006). By this time there were nine such banks in the country (Wikipedia, 2009). In 1972, the Mit Ghamr Savings project became part of Nasr Social Bank which, currently, is still in business in Egypt.

Since it was first implemented in its modern form by Grameen Bank in the 1970s to help impoverished Bangladeshis, microfinance has grown dramatically both in terms of the number of clients reached and the types of products offered. It is now a standard development tool promoted across the globe to tackle poverty through support for small enterprises. It was originally provided by non-governmental organizations (NGOs), but the appeal of microfinance drew more players to the table and there is now a wide range of providers including commercial and state banks, insurance companies, and telecommunications companies. Some of these providers emphasize only social impact; while others base their models on a double bottom line taking into account both social impact and fiscal performance. In conventional microfinance, interest is a central element of the lending model. Conventional microfinance is often criticized for requiring high interest rates on loans that are designed to help alleviate poverty, which seems unfair for MFI clients. High interest rates are required to cover the cost of borrowing money, any default losses, and transaction costs. When spread over the smaller loan amounts that define microfinance, these costs do amount to relatively high interest rates. For example, the average interest rate in 2006 was 28\% (Consultative Group to Assist the Poor, 2012). While this model is designed to promote sustainability in its coverage of all costs for the MFI, the resulting interest rate is much higher than the rate on standard loans in developed countries.

Microfinance is a concern for Muslims and shows great opportunity for growth for Islamic financial organizations. An estimated 72 percent of people living in Muslim-majority countries do not use formal financial services (Patrick, 2007). In this regard, often either because they are not available, and/or because the potential customer believe that conventional lending products are incompatible with Islamic law (Nimrah, 2008). According to the Islamic Microfinance Network website imfn.org (as of circa 2013), there are more than 300 Islamic microfinance institutions in 32 countries (Khan, 2013). But a number of studies have found that outreach has far to go. One report (by Humayon Dar and coauthors) as cited in Mughal (2015) found that Islamic microfinance made up less than 1 per cent of the global microfinance outreach, "despite the fact that almost half of the clients of microfinance live in Muslim countries and the demand for Islamic microfinance is very strong" (Khan, 2013).

A 2008 study of 126 microfinance institutions in 14 Muslim countries, as cited in (Nimrah, et al., 2008) found Islamic microfinance had a total outreach of 380,000 and Dar, et al., (2012) provided that from estimated total population of 77 million - only $0.5 \%$ "of total microfinance outreach". The largest Islamic microcredit outreach was Bangladesh, with over 100,000 clients and two active institutions, but this compared with nearly 8 million borrowers using conventional microfinance products (such as those of the Grameen Bank leaving Islamic microfinance with only $1 \%$ of the Bangladesh microfinance market. The total outstanding loan portfolio for Islamic Microfinance institutions studied was about $\$ 198$ million in 2006, with an average loan size of $\$ 54$ (Nimrah, 2008). Muhammad Yunus the founder of the Grameen Bank and microfinance banking, and other supporters of microfinance, though not part of the Islamic Banking movement, argue that the lack of collateral and lack of excessive interest in micro-lending is consistent with the Islamic prohibition of usury, that is, Riba (Hassan, 1994). 
Abdulrahman (2007) cited in Elzahi (2015) investigated Islamic microfinance as a missing component in Islamic banking. His investigation revealed that despite the main objectives of microfinance, poverty alleviation and enabling the poor to be empowered in line with the principles of Islamic values has not been addressed reasonably by Islamic banks. Sa'ad (2011) cited in Elzahi (2015) investigated various income generating activities financed through microfinance institutions in Malaysia. The study used survey to indemnify which activity is viable to the microfinance institution and in generating high income. While the study identified some high-income generating activities, it was discovered that the microfinance receiver lack the proper skills. Salwana, et al. (2013) cited in Elzahi (2015) showed that traditional microfinance has failed to satisfy the Muslims communities because of its shift from poverty to focus on profit-oriented business. In addition to that, conventional microfinance loan being granted based on interest rate (riba from an Islamic point of view) is not tailored to the Muslims beliefs.

The easiest way to reduce interest rates would be to get MFIs to operate more efficiently and reduce administrative costs, which can be very high for small organizations. Unfortunately, this may incentivize MFIs to provide larger loans to more affluent clients so that the per capita overhead is lower (Rehman, 2007). It is therefore a delicate balance to manage interest rates and outreach to those in greatest need. In the world we live in, characterized with low development, the rich getting richer by the day, and security of lives and properties not guaranteed. Interestingly, there are icons who have etched their names in gold through their marvelous contributions to the economic development. One name that has found itself in this league of iconic figures that deserve a garland is Muhammad Yunus: a successful businessman, a banker and a philanthropist who initiate, organize and operate a cost-effective enterprise.

Clemens and Gabriel (2013) cited in Elzahi (2015) investigated the new transparency in Development Economics: Lessons from the Millennium Villages Controversy. They found that there is a weakness in the claims of the World Bank to end extreme poverty by the year 2030. Furthermore, they added that the claim of the success of ending poverty might depend on the right programs and policies. It's in line with this thinking that, Brackman and Jeffe (2008) observed that, amid the aftermath of the catastrophic floods of 1974 in Bangladesh, a young American-trained economist named Muhammad Yunus visited a ruined village to see how he could help. A group of families approached him and refused his offers of charity. Give us a small loan, they told him, and we will use it to start a business using our crafts. Once they started making money, they told Yunus, they could repay the loan as well as rebuild their homes and lives.

As a matter of fact, Brackman and Jeffe (2008) provided that, Yunus lent the families twenty-seven dollars. They repaid the loan quickly and they rebuilt their village while the surrounding villages remained stagnant. The experience gave Yunus an idea. We all know, he thought, that poor people don't have enough food, health care, and access to education. But may be the thing that is really holding them back is the fact that they have no ability to borrow money. So he created a lending institution called Grameen Bank (which means "Bank of the Villages" in the Bangla language) whose sole purpose was to lend small amounts of money to the rural poor that could be use start new small businesses. Thus was born a new financial term; "microcredit". The Grameen Bank has done tremendous good work in the last three decades. It has loaned out billions of dollars to more than six million Bangladeshis. It has empowered villagers, mostly women, to create new lives for themselves above and beyond what was possible prior to its establishment. And it has inspired hundreds of similar institutions throughout the world, in countries rich and poor, all of which are attempting to do some form of poverty alleviation through microcredit loans.

\section{Conceptual issues surrounding Islamic microfinance}

The Koran and Islamic law provide important social elements that both align with and improve upon the goals of conventional microfinance. This makes Islamic microfinance a compelling choice for impoverished and unbanked Muslims across the globe. Challenges to expanding the reach of Islamic microfinance remain. For one, the funding models supported by Sharia scholars require greater attention from the financier because the risk is shared between the MFI and the client. This requires more time and overhead for each client. Thus, the number of potential clients may not be as high for Islamic MFIs as for conventional MFIs. It may also have the positive result of increasing the likelihood that the financier will work with the client and focus more on the success of the project than on the ability of the client to repay a loan. Second, the avoidance of interest means that there is not a reliable cash flow with which to earn income that can be used to extend loans to additional clients. This creates challenges for both the sustainability and growth of Islamic MFIs. It also means 
that there is less likelihood that Islamic MFIs will overreach, which increases the ability of each financier to work closely and develop relationships with their clients, which may in turn lead to greater long-term health of the MFI. While the challenges are important to consider, the benefits of Islamic microfinance could be an effective tool for impoverished groups in Muslims countries (Hurlburt, 2012).

While conventional microfinance is well developed, with wide reach across the globe, Islamic microfinance has yet to penetrate its potential market. According to a survey by the Consultative Group to Assist the Poor, the total number of Islamic microfinance accounts and clients in 2007 was 380,000, which made up only $0.5 \%$ of the microfinance industry's total outreach (Nimrah, et al., 2008). There are strong arguments for its expansion. An estimated $72 \%$ of people living in Muslim-majority countries, such as Somalia, can be defined as "unbanked" because they do not have access to traditional financial services offering lending and savings components (Ibid). Furthermore, of the world's approximately 1.7 billion people who live below the poverty line, $44 \%$ reside in Muslim countries (The Nation, 2011). In Somalia, the majority of its ten million citizens fall into this category. These figures indicate that there are millions of people who could benefit from Islamic microfinance.

There is broad scholarly support for expanding and developing Islamic microfinance. The 2009 case study of Pakistan emphasizes that combining the Islamic social principle of caring for the less fortunate with microfinance's power to provide financial services access to the poor has the potential to reach out to millions more people (Akhter, et al.). In support of expanding Islamic MFIs, it is frequently noted that microfinance as a poverty alleviation tool is well aligned with the principles of Islam. "Islam views poverty to be a curse to be eradicated through productive efforts...there is therefore a convergence between the objectives of Islam and the avowed aims of 'best practices' microfinance (Obaidullah, 2007). Specifically, the concept of helping the poor is directly supported under the third of the five pillars of Islam; zakat, meaning giving support to the needy.

Scholarly support for Islamic microfinance is mirrored in the expansion of organizations providing resources on the topic. The Islamic Microfinance Network was formed in 2011 to provide a common platform for Islamic MFIs around the world by coordinating the efforts of its members in jointly addressing poverty alleviation, establishing best practices in Islamic microfinance, and developing guidelines for adopting practices that comply with Sharia law.10 There are also financial resources available. The Islamic Development Bank committed $\$ 500$ million to expand the reach of Islamic microfinance throughout the world. There are currently no specific plans to direct these funds to Somalia, but this shows that there are groups and funds available to provide these resources (Hurlburt, 2012).

Islamic microfinance differs from conventional microfinance in that it must adhere to the same principles as Islamic finance, which is structured to provide products for Muslim customers that are in compliance with the code of ethics and conduct laid out under Sharia law. It utilizes a range of models to avoid elements forbidden under Sharia, namely interest (riba) and uncertainty and deceit (gharar). Financial instruments are therefore designed to provide funds in a manner that avoids both interest payments while still taking into consideration the need to cover overhead and the cost of financing if the MFI is to be sustainable, and shares the risk of the investment between the financier and recipient or places it on the MFI alone (Hurlburt, 2012).

\section{Islamic microfinance as panacea to high rate of poverty among poor/low income families}

From a global perspective, microfinance organizations envision a world in which low-income households have permanent accesses to a range of high quality and affordable financial services offered by a range of retail providers to finance income-producing activities, build assets, stabilize consumption, and protect against risks (Project Concern International, 2016). In Nigeria, the Microfinance institutions were established to enhance and provide the flow of financial services to meet the need of poor and low income groups who engages in agricultural sector and non-farm activities such as trading, tailoring, weaving, blacksmithing, agro-processing and transportation, etc., through an appropriate menus for both rural and urban poor (Adamu, et al., 2010).

Many rural areas are disadvantaged in Muslim countries particularly in central Asia, sub-Sahara Africa and MENA region. They have no proper access to the formal lending and to conventional or Islamic financing. Moreover, the lending institutions are not even well-spread enough to reach out to the needy. Private and foreign banks that seek to maximize their profits are concentrating only on the urban cities. Poor projects are left only to public banks because of the high risk that is associated with lending to the poor or micro producers. Given the rate of high poverty among these low-income groups and the unavailability of collateralization 
mechanism, lending to this group is normally associated with greater risk as reflected in the banks' high nonperforming loans in some countries like Morocco (Hurlburt, 2012).

Because majority of people in Muslim countries are Muslim by birth, Islamic Microfinance is one way to meet the financial needs of these people. However, this will enable them to achieve better financial inclusions even for the non-Muslim poorest minority living among them. Islamic microfinance can provide small loans for the poor people or people with good expertise without any start-up capital. Unlike conventional microfinance, Islamic microfinance generated its vision from Islamic worldview. Therefore, it grants finance to the needy for self-employment based on Maqasid al-Shari'ah.

Islam always encourages self-employment rather than just donating money and food to the needy for consumptions. However, providing tools for production to poor people is better than the donation of consumable charity (Hadith). The poor people who are self-employed will be empowered to care for themselves and their families. Furthermore, the World Bank declared the microfinance as a means of inequality and poverty eradication. Islam has more means of eradicating income inequality such as Zakat and Sadaqah which is given directly to the needy to solve their urgent needs. Hence, Islamic microfinance targets the very poor people who are capable of working in the production of goods or services. Consequently, while Zakat and Sadaqah should be paid only to specific people, Islamic microfinance is not (Hurlburt, 2012).

Islamic microfinance can be used to mitigate the negative impact of the high unemployment rate among the youth in Muslim countries. Evidence has shown that the rate of unemployment is skyrocketing in the world among the adult and youth at same time in most Muslim countries. Islamic microfinance can be used as a quick response, targeted to finance small entrepreneurship such as Small and Medium-sized Enterprises (SMEs). Hence, Islamic microfinance can be used effectively to overcome the problem of hyper unemployment and the challenges facing SMEs in accessing suitable finance in Muslim countries. As the case of other Muslims countries, the Sudanese experience showed that Islamic microfinance has a positive impact on income generating activities. In addition, Islamic microfinance used to finance graduate students as a part of the unemployed youth sector in Sudan (Elzahi, 2015).

Despite the positive impact of Islamic microfinance in many Muslim countries, the borrowers are still dominated by the traditional sectors. Unfortunately, most of these sectors faced more challenges in most Muslims countries. These challenges include but are not limited to the basic infrastructures, financial infrastructures, and far and unreachable markets. These challenges have negatively impacted the accessibility of Islamic microfinance by raising the cost of finance in many Muslim countries (Elzahi, 2015).

Other challenges facing Islamic micro-finance in Muslim countries is high cost and the riskiness of financing poor borrowers. This stems from the small size of their finances, the remote residential areas of the poor from the urban cities, and their uncollateralized risk. Thus, the projects executed by the poor are always of small scale in nature and they always lived in very remote and even sometimes, primitive areas in Muslims countries. In addition, Muslims countries only recently recognized the essentiality of microfinance as a tool of empowering low-income group, reducing the problem of unemployment, and elevating poverty. Also, the weakness of the Islamic microfinance infrastructures includes the limited spread of Islamic financial institutions and the relevant financial regulations, and the unavailability of popular Islamic micro finance agencies or effective program in these countries (Elzahi, 2015).

\section{Conclusion and recommendations}

Islamic Microfinance is very effective and essential for creating hope not only for the poor and those above the poverty line as shown by the traditional microfinance, but also for the extremely poor in the community. However, Muslims who are extremely poor remained excluded through traditional microfinance for several reasons. They were excluded voluntarily due to the practices of the interest rate by conventional lending institutions which considered Riba which is forbidden in Islam. Similarly, it can be excluded non-voluntarily due to inability to repay back the loan plus the interest rate accrued to it. Thus, Islamic microfinance can easily overcome these challenges due to its wide scope to cover various diversity of customer whether based on their expertise or sectorial dimension. This is in addition to its supported tools such as Zakat, Waqf, and Sadaqah. With the afore said in our minds, this paper considered Islamic microfinance as a tool that could be used to achieve the necessary economic and social security that a country would need today leading to the overall development of humanity. This study, in general, recommended for the revitalization of Islamic civilization 
that would geared towards a paradigm shift to now novel concept of spiritual microfinance as a way to stimulate business and get closer to God simultaneously and as well stimulates social entrepreneurs who must focus on the goal of having a healthy income statement and simultaneously championing some sort of social healing enterprise.

Author Contributions: conceptualization, Bello, H.S., Isah, M., Lame, D.M.; methodology, Bello, H.S., Isah, M., Lame, D.M.; validation, Bello, H.S., Isah, M., Lame, D.M.; formal analysis, Bello, H.S., Isah, M., Lame, D.M.; investigation, Bello, H.S., Isah, M., Lame, D.M.; resources, Bello, H.S., Isah, M., Lame, D.M.; data curation, Bello, H.S., Isah, M., Lame, D.M.; writing - original draft preparation, Bello, H.S., Isah, M., Lame, D.M.; writing - review and editing, Bello, H.S., Isah, M., Lame, D.M.; visualization, Bello, H.S., Isah, M., Lame, D.M.; supervision, Bello, H.S., Isah, M., Lame, D.M.; project administration, Bello, H.S., Isah, M., Lame, D.M.

\section{References}

1. Adamu, Y., Wuro, B. and Ali, M. (2010). Appraisal of Microfinance as a source of funding small scale enterprises in Gombe state. Proceeding of the $24^{\text {th }}$ Annual Conference of Farm Management Association of Nigeria. Adamawa State University Mubi, $11^{\text {th }}-14^{\text {th }}$ October, 132-136.

2. Akhter, W., Nadeem, A. and Syed, K. A. J. (undated). Islamic Micro Finance and Poverty Alleviation: a Case of Pakistan. Retrieved from: https://akhuwat.org.pk/islamic-micro-finance-and-poverty-alleviation-acase-of-pakistan/

3. Ariff, M. (1988). Islamic banking. Asian-Pacific Economic Literature 2 (2) (September), 46-62. Retrieved from: https://onlinelibrary.wiley.com/doi/abs/10.1111/j.1467-8411.1988.tb00200.x

4. Brackman, L. and Jaffe, S. (2008). Jewish Wisdom for Business Success: Lessons from the

Torah and Other Ancient Texts. New York: American Management Association Publications. Retrieved from: https://www.amazon.com/Jewish-Wisdom-Business-Success-2008-09-10/dp/B01K3OPTP8

5. Cengiz, E. and Radi, E., (1989). Attitudes, Behaviour, and Patronage Factors of Bank Customers towards Islamic Banks, International Journal of Bank Marketing, 7(6), 31 - $\quad 37 . \quad$ Retrieved from: https://ibtra.com/pdf/journal/v8_n 4 article6.pdf

6. Choudhury, M.A. and Malike, U.A. (1992). The Foundations of Islamic Political Economy, London: Macmillan; New York: St. Martin's Press, 104. Retrieved from: https://www.palgrave.com/ gp/ book/9780333547045

7. Consultative Group to Assist the Poor. (2012). Why Do MFIs Charge High Interest Rates? Retrieved from: http://www.cgap.org/about/faq

8. Dar, H. A. (2010). Islamic banking in Iran and Sudan. Business Asia, 27 June. Retrieved from: http://www.humayondar.com/businessasia4.pdf

9. Dar, H. A., Rizwan, R., Rizwan, M. and A. K, (2012). Global Islamic finance report 2012. London: Edbiz Consulting. Retrieved from: https://issuu.com/isfire11/docs/isfire_2012-may_issue

10. Elzahi, S.A.S. (2015). Islamic Microfinance: Moving beyond Financial Inclusion, European Scientific Journal, April 2015 Edition, 11(10). Retrieved from: http://eujournal.org/index.php/esj/article/view/5427

11. Hassan, Z. (1994). The Redefinition of Islamic Economics. The Daily Star, August 27. Retrieved from: https://www.researchgate.net/publication/281335131_Islamic Commercial Banking_Systems A Theoretic al Comparison

12. Hurlburt, K. (2012). What is Islamic Microfinance? Retrieved from https://www.researchgate.net/publication/338987958 Prospects and Challenges of Islamic Microfinanc $\mathrm{e}$ in Turkey Prospects and Challenges of Islamic Microfinance in Turkey

13. Karim, N., Tarazi, M., Reilli., Z. (2008). Islamic microfinance: An emerging market niche. Retrieved from https://www.c.gap.org/sites/default/files/CGAP-Focus-Note- Islamic-Microfinance-An-EmergingMarket-Niche-Aug-2008.pdf

14. Kepel, G. (2006). Jihad: The Trail of Political Islam. I.B. Tauris, 77. Retrieved from: https://www.hup.harvard.edu/catalog.php?isbn=9780674010901 
15. Medha, R. (2011). Islamic Microfinance Network (IMFN) launches in Pakistan, will serve Shariah micro lenders worldwide: Micro Capital Brief. Retrieved from: http://www.microcapital.org/microcapitalbrief-islamic-microfinance-network imfnlaunches-inpakistan-will-serve-shariah-microlendersworldwide/.

16. Mervyn, K. L. \& Latifa M. A. (2001). Islamic Banking. Cheltenham. Edward Elgar Publishing. Retrieved from: https://econpapers.repec.org/RePEc:elg:eebook:1488

17. Mughal, M. Z. (2015). Sources for Islamic Microfinance Funding Institutions. AlHuda Centre of Islamic Banking \& Economics. Retrieved from http://imfn.org/funding-sources-ismfis

18. Nimrah, K., Michael, T. and Xavier, R. (2008). Islamic Microfinance: An Emerging Market Niche, CGAP Focus Note, 49. Retrieved from: http://www.cgap.org/publications/islamicmicrofinance-emergingmarket-niche.

19. Obaidullah, M. (2007). Islam, Poverty and Micro Finance 'Best Practices. Institute of Halal Investing. Retrieved from: http://instituteofhalalinvesting.org/content/Islam and poverty.pdf

20. Patrick, H. (2007). Cross-country variations in household access to financial services. Presented at the World Bank Conference on Access to Finance, Washington, D.C., 15 March, 1. Retrieved from: http://citeseerx.ist.psu.edu/viewdoc/download?doi=10.1.1.170.9339\&rep=rep1\&type=pdf

21. Project Concern International (2016). Microfinance in Africa. Retrieved from: www.PCIGlobal.org.

22. Ravi, M. (2011). Islamic Microfinance Network (IMFN) Launches in Pakistan, Will Serve Shari'ah Micro lenders Worldwide, Micro Capital Brief, February 1. Retrieved from: http://www.microcapital.org/microcapital-brief-islamic-microfinance-network-imfn- launches-inpakistanwill-serve-shariah-microlenders-worldwide/

23. Rehman, A. A. (2007). Towards Islamic Microfinance: A Primer; CGAP Microfinance Gateway. Retrieved from: http://www.microfinancegateway.org/p/site/m/template.rc/1.26.9091/.

24. The Nation. (2011, April 25). 44pc of Poverty-hit Live in Muslim Countries. Retrieved from: http://www.nation.com.pk/pakistan-news-newspaper-daily-english-online/business/25- Apr-2011/44pc-ofpovertyhit--live-in-Muslim-countries

25. Wikipedia (2009). Islamic Banking. Retrieved from: http://www.usc.edu/dept/MSA/economics /islamic banking.html Archived

26. Wilson, R. (1983). Banking and Finance in the Arab Middle East, St Martin's Press, New York. Retrieved from: https://www.palgrave.com/gp/book/9781349048199

27. Zekri, S (2013). Towards an inclusive vision of micro finance in Tunisia. Journal of Business Studies Quarterly 2013, Volume 5 Number 2. Retrieved from: https://www.jstor.org/stable/43503855

28. Zubair, M. M. (2014). Islamic Microfinance education: the critical need, opportunity and way forward. Retrieved from: http://coaching.Yurizk.Com/yblc2014/ 